\title{
An Enhanced E-Learning Application for Tertiary Institutions
}

\author{
U. F. Eze \\ Federal University of Technology, \\ Owerri \\ Department of Information \\ Management Technology
}

\author{
M. E. Ihuoma \\ Federal University of Technology, \\ Owerri \\ Department of Information \\ Management Technology
}

\author{
N. C. Ajanwachuku \\ Gregory University, Uturu \\ Department of Computer Science
}

\begin{abstract}
An enhanced E-learning platform took into consideration vital concerns of its target population (teachers and the learners). Also, it provided a conducive environment for teachers to carry out their teaching effectively and efficiently. It does also provide the same atmosphere for students (learners) to enjoy quality education. The main objective of this study is to design an enhanced E-learning application for a tertiary institution. To achieve this aim, existing E-learning applications were evaluated based on identified performance indicators (communicativeness of interface, security and system upgrade). Based on the limitations of the existing Elearning applications (Module, Blackboard and Edmodo ELearningg applications) a logical and physical system for the proposed system was designed, and the unique system was also evaluated based on identified performance indicators. The analysis of the proposed system was carried out using the Object-Oriented Analysis and Design Methodology (OOADM). This study also presented the model, system design and formal description of the e-learning system. Subsequently, the architectural design was implemented using the Apache Wamp Server, MySQL and PHP web technology tools on the backend. In contrast, HTML, CSS, and JavaScript technologies were used on the front end. The result of the design was a prototype system that was developed which has a better communication interface, security and system upgrade capabilities. To enjoy a better feel of security, a firewall system was integrated into E-learning platforms to filter out the activities of unsolicited traffic to the web platform.
\end{abstract}

\section{Keywords}

E-Learning, Security, Upgrade, Communication Interface, Enhanced.

\section{INTRODUCTION}

Each time the word Education is spoken of, the classroom system is envisaged by many. The thought of people receiving lessons from teachers in an enclosed space called classroom comes to mind. However, the advent of technology and the internet is gradually overturning such thoughts or impression about education. E-learning is a concept that emerged from technological and internet advancement of this present era and is gradually being integrated into many tertiary educational programs, thus resulting in a paradigm shift from the traditional method of education to an electronic method in which students can have access to instructional resources irrespective of time and location. [1] defines E-learning as using electronic media such as the internet, DVD, CD-ROM, videotape, television, cell phones, etc. for teaching and learning at a distance. Why adopt this concept of learning at the tertiary level of education? The reason being that Elearning enables learners to broaden their knowledge horizon since learning is self-paced and results in the improvement of learner's level of confidence and independence [14]. The Nigerian government has made a promise to improve the Information and Communications Technology (ICT) skills of its people and to bridge the digital divide by targeting Nigerian higher institution [2]. The Federal Republic of Nigeria (2004:53)[3] earlier stated that "the government shall provide facilities and necessary infrastructure for the promotion of ICT and e-learning." These commitments are in line with that of the New Partnership for Africa's Development to attain sustainable development in the $21 \mathrm{st}$ century. Hence, e-learning, as a component of ICT, has suffered some setbacks. The existing e-learning platforms (Moodle, Blackboard and Edmodo E-Learning applications) have limitations in areas such as security, system upgrade, and communicativeness of interface. These problems have made it very difficult for many students both at home and abroad to enjoy learning programmes from this innovative platform. The enhanced e-learning platform will improve on the existing e-learning system, which is in line with the Nigerian government's objective to bridge the digital divide through elearning platforms to achieve sustainable development in the economy. The enhanced e-learning system will provide better security, system upgradeability, and communicativeness of interface. This paper is organized as follows: section two presents a review of related works. Section three describes the proposed system, its architecture, implementation, and test, Section four presents the result and discussion, and finally, section five concludes the work.

\section{LITERATURE REVIEW}

\subsection{Review of Empirical Framework}

In recent years, different needs of versatile e-learning have pulled in consideration of numerous scientists in computer sciences and information fields. Subsequently, various works have been done toward versatile e-learning frameworks, which are displayed beneath.[4] Designed an extended elearning platform called i-coverage which incorporates social networking approach to improve the learning experience in Universities. It also has a comprehensive learning platform that allows for the exchange of information between stakeholders in the University in a simplified and consistent manner. [5] Focused on providing comprehensive guide on designing and implementing e-learning courses for trainers and instructional designers who are new to e-learning design. It also provides basic concepts and information on the processes and resources involved in e-learning development, which might be of interest to capacity-development managers. [6] Investigated the application of e-teaching and e-learning in Nigerian educational system. Result of their research shows that Nigeria has been slow when it comes to implementing ICT infrastructures in most of the Universities in the country 
due to poor policy making, poor information infrastructure, poor implementation strategies, and lack of steady electrical power supply and this has affected the adoption of e-teaching and e-learning in most tertiary institutions across the country. [7] Developed a customized web-based virtual classroom system (webVCS) model, which is a substitute teaching or learning system to the traditional approach. However, for the smooth functioning of the system, factors such as internet facilities and availability of computers even at remote locations need to be addressed. [8] Designed and implemented a robust system that integrated both intranet-based communication and e-learning together. The synergized platform provides institution-wide communication and remote learning with the aid of local intranet networks already available in most of the Nigerian Universities at a little cost. [9] Presents the adoption of cloud computing in tertiary institutions intending to make higher educational processes seamless. [10] Used component-based software to design a computer-based testing system. The concept of reuse in object programming is evident in this work. Multiple components of the software were achieved by reusing single-core components again and again. However, it should be noted that each reused single component differs from the other, though having the same template format. [11] Presents an overview of e-learning and the conditions required for individuals to benefit from it maximally. The work also highlighted the status quo and challenges of implementing e-learning in developing countries. The work further proffers solutions to the challenges of implementing e-learning in developing countries.

\subsection{E-Learning Equipment and Materials in Nigeria's Tertiary Institutions}

Tertiary institutions in Nigeria recognized the fact those with physical disabilities in the country should be given special educational consideration. With that viewpoint in mind, elearning is seriously encouraged to achieve this purpose. The government supports these physically challenged individuals by providing learning equipment such as overhead projectors, slides, smart boards, circuit television (CCTV), transparencies, magnifiers, and computers with special devices for operating complex functions. However, these elearning equipment are not enough when compared to the number of individuals that needs it, and learning resources such as e-books, special reading devices, television conferencing infrastructure lack in most Nigerian tertiary institutions [12].

\section{SYSTEM ARCHITECTURE AND IMPLEMENTATION \\ 3.1 System Architecture}

The e-Learning system makes use of a relational database, Web Services and Web Pages. This connects all other modules of the application. User interactions are being passed to these modules, and then results are generated and passed back to the user-end. Within this system has some set of middleware that filters interactions and applies security measures as integrated into the system. Figure 1 shows the architectural system design.

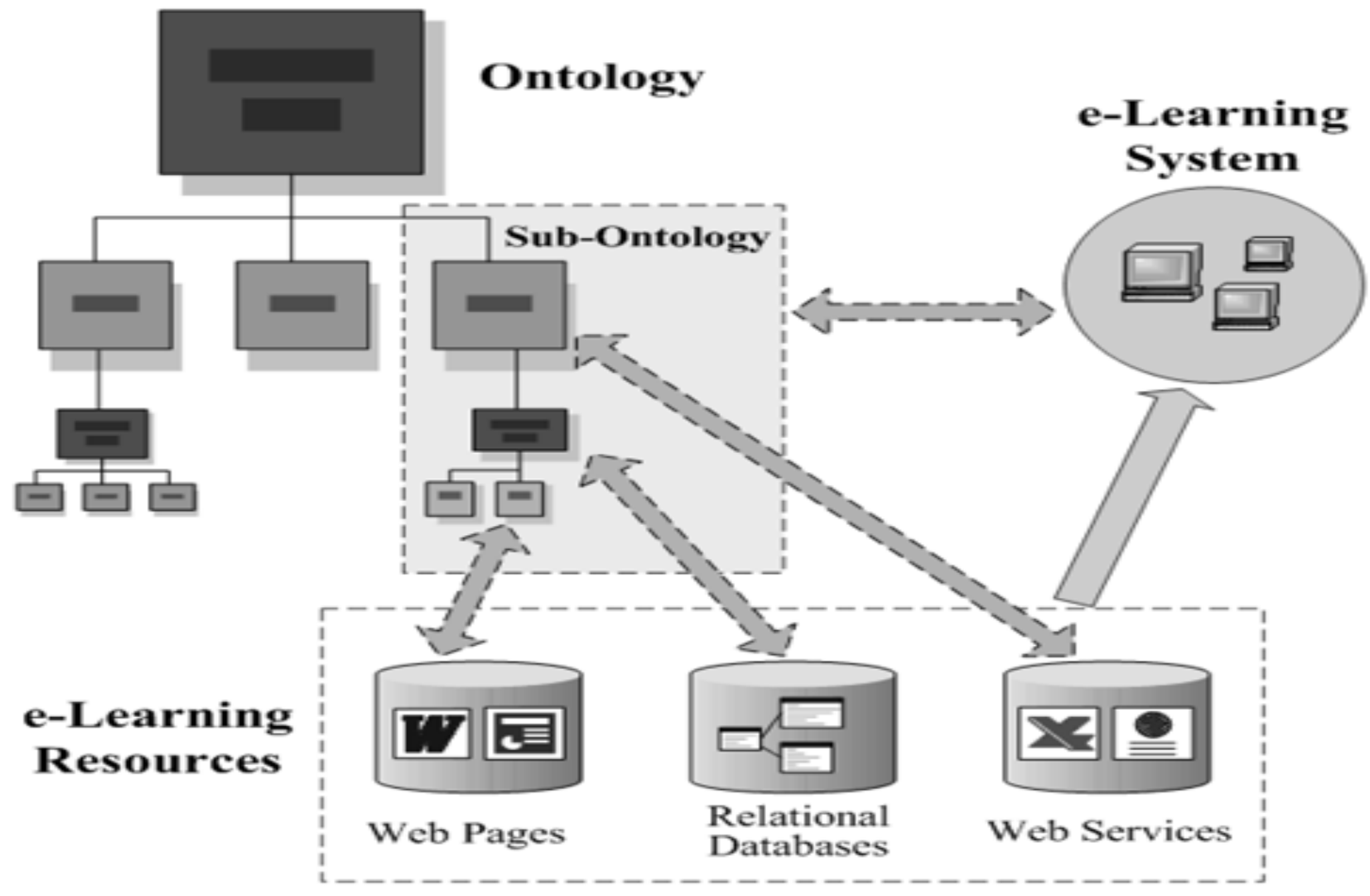

Figure 1: System Architectural Design

\subsection{Physical System Design}

The screenshot of the input/output design is shown in this section.

\subsubsection{Input Design Screenshot}

(a) Login Form: The login form (figure 2) presents the user with options for entering the username, which serves as the user I.D. and the password which will authenticate the user. 


\section{My Acoount}

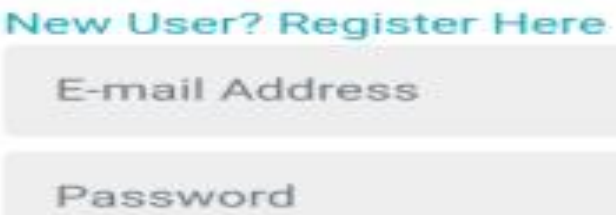

Forgot Your Password?

\section{LOGIN NOW}

\section{Figure 2: Login Form}

(b) Admin Area and New User Page: The admin area page, as shown in figure 3, is an overview of the various administrative tasks that the admin can perform. The screenshot below displays the admin area page in figure 3 and the new user page in figure 4 .

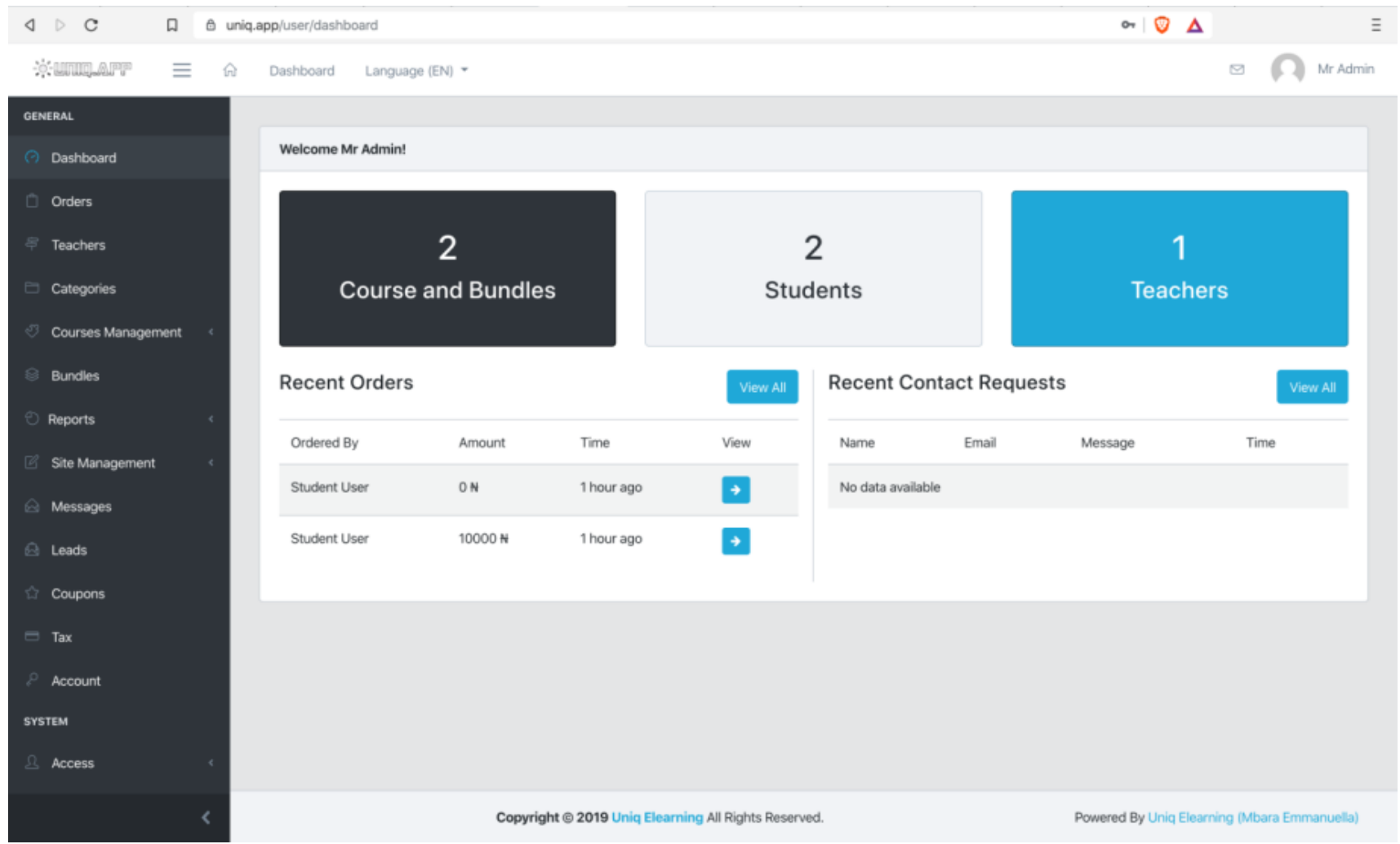

Figure 3:Admin Area Page 


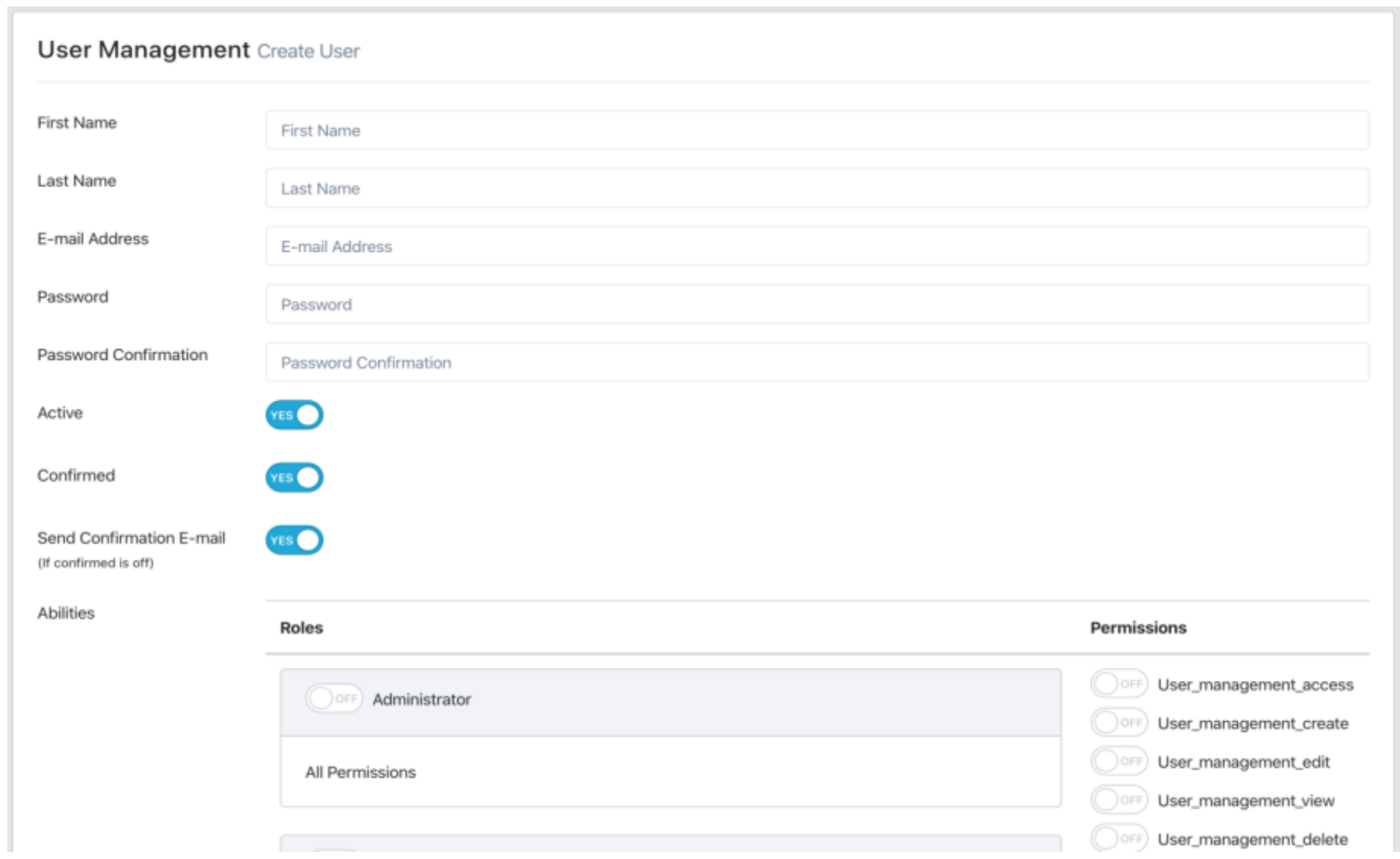

\section{Figure 4: New user Page}

(c) Change Password Page: The change password page, as shown in figure 5, allows the admin to change the user password of any login account.

\section{My Account}

\section{Profile Update Information Change Password}

\section{Old Password}

Old Password

Password

Password

Password Confirmation

Password Confirmation

\section{Figure 5: Change Password Page}

(d) User Profile Search Page: The User profile page, as shown in figure 6, allows the admin to search for a user profile of the elearning system. The user clicks on the user profile link to view a user record. 


\section{User Management Active Users}

\begin{tabular}{|c|c|c|c|c|c|c|c|c|c|c|}
\hline Last Name & First Name & E-mail & Confirmed & Roles & Other Permissions & Social & Last Updated & \multicolumn{3}{|c|}{ Actions } \\
\hline Admin & Mr & admin@uniq.app & Yes & Administrator & N/A & None & 8 minutes ago & 0 & $\mathbb{Z}$ & More \\
\hline User & Teacher & teacher@uniq.app & Yes & Teacher & $\mathrm{N} / \mathrm{A}$ & None & 4 hours ago & 0 & $\mathbb{G}$ & More ${ }^{-}$ \\
\hline User & Student & student@uniq.app & Yes & Student & $\mathrm{N} / \mathrm{A}$ & None & 4 hours ago & 0 & $\mathbb{Z}$ & More - \\
\hline User & Normal & user@uniq.app & Yes & Student & $\mathrm{N} / \mathrm{A}$ & None & 4 hours ago & 0 & 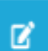 & More - \\
\hline
\end{tabular}

4 users total

\section{Figure 6: User Profile Search Page}

(e) Site Debug Dashboard: The site debugs dashboard, as shown in figure 7, allows the admin to view all logs made by the application while it is running. This will hence assist the admin in debugging the app and effect necessary applications updates.

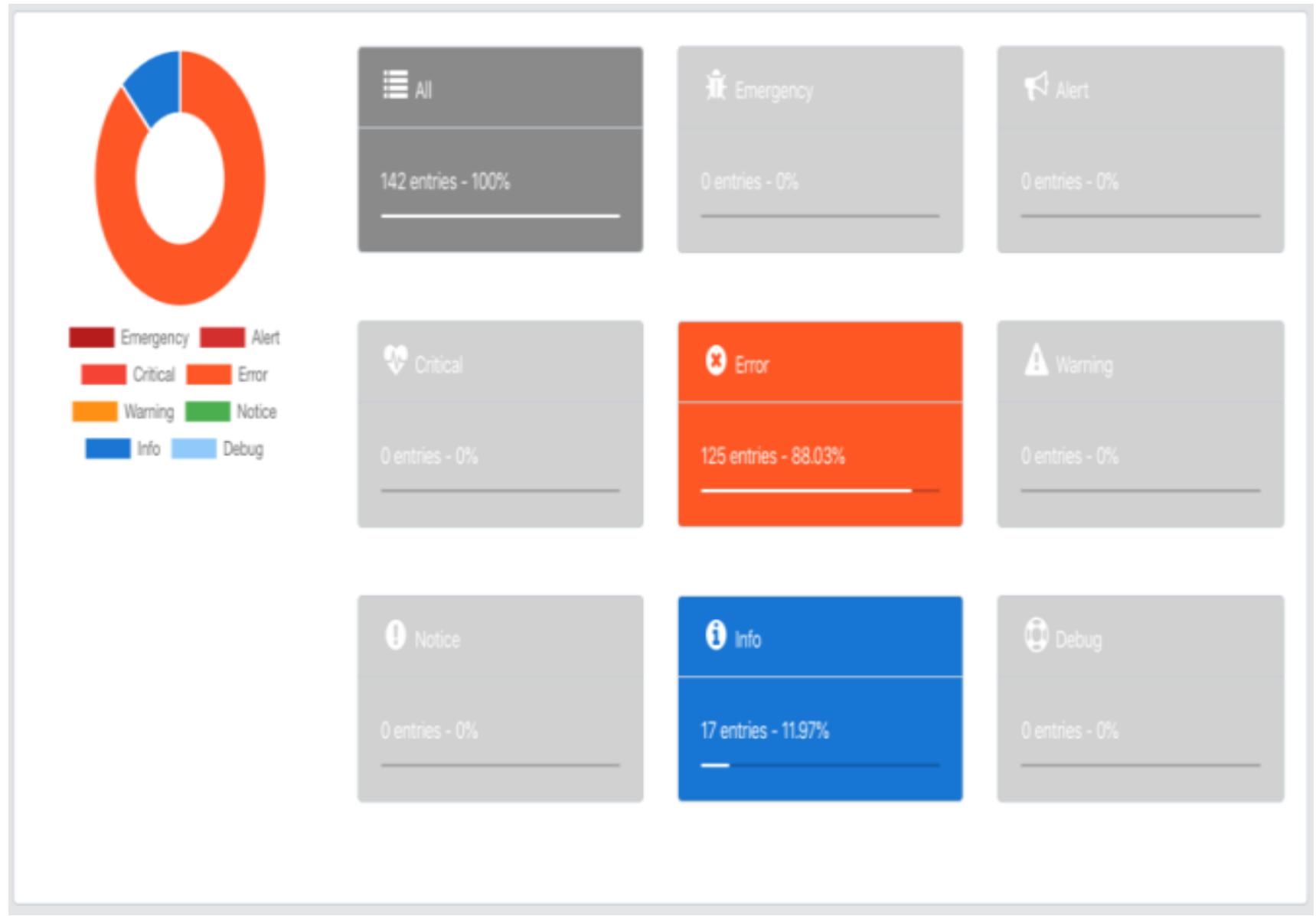

Figure 7: Site Debug Dashboard

(f) Subscribe Page: The subscribe page, as shown in figure 8, allows the users to subscribe to the e-learning platform's newsletter; all necessary updates will be communicated via this medium. 


\section{내.АРP}

\section{We take our mission of increasing global access to quality education seriously. We connect learners to}

Figure 8: Subscribe Page

(g) New Course Page: The new course page, as shown in figure 9, allows the admin to add courses to the e-learning system.

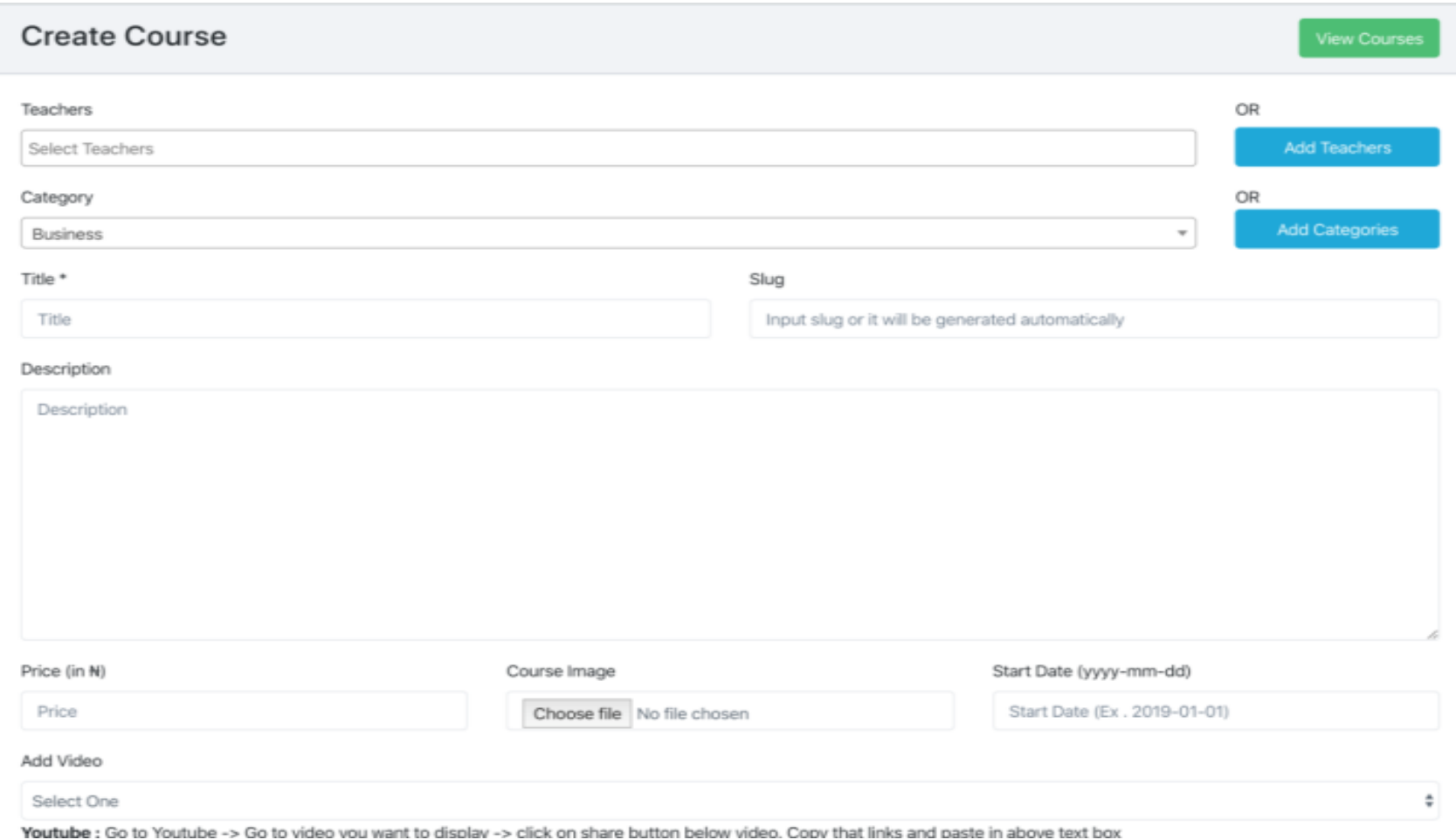

Figure 9: New Course Page

(h) User's Role Management Page: The role management page, as shown in figure 10, allows the admin to manage each user's roles and permissions on the e-learning system. 


\section{Role Management}

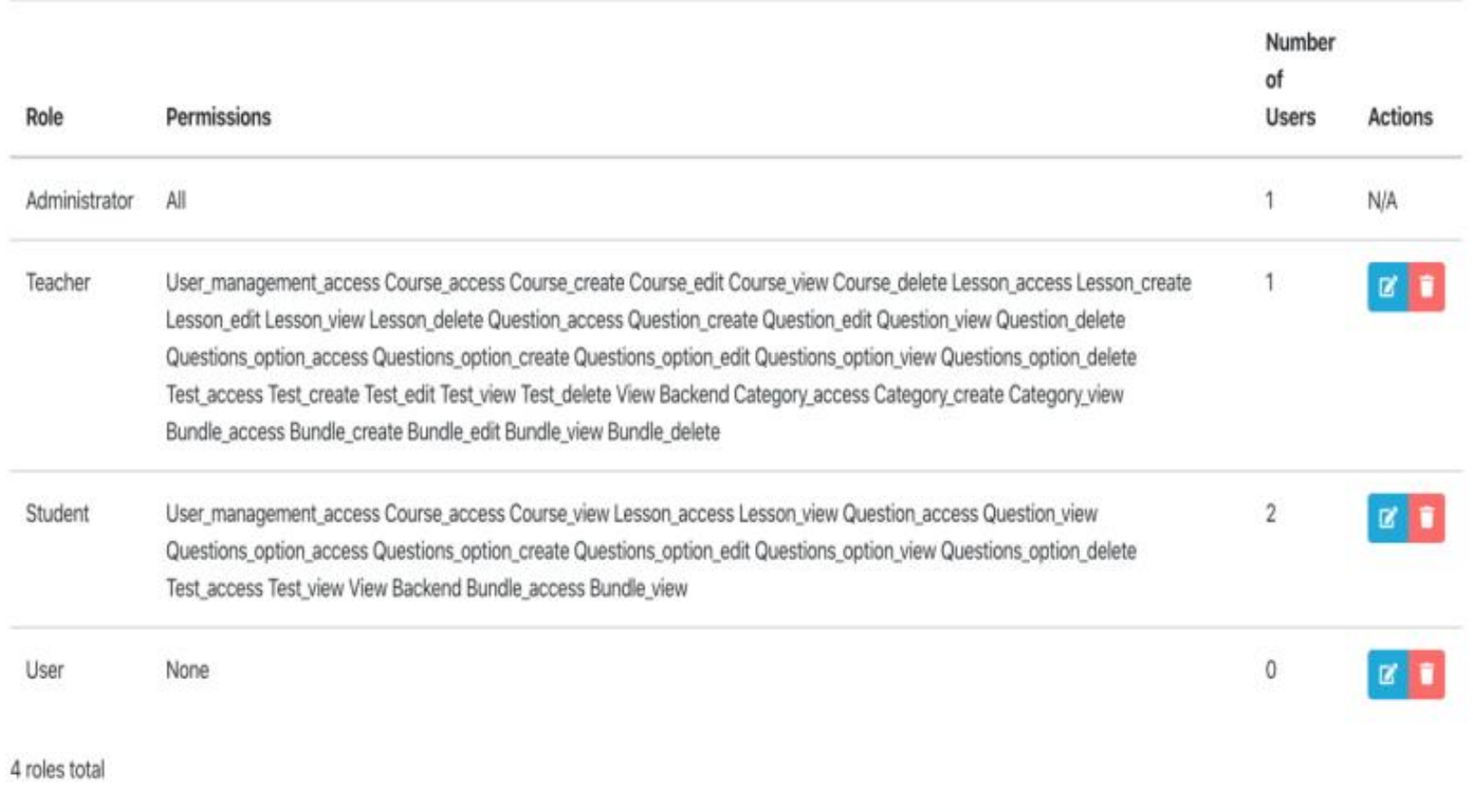

\section{Figure 10: User's Role Management Page}

(I) Generate Certificate Page: The Generate Certificatepage, as shown in figure 11, allows the admin to generate attendance certificates for students.

\section{Certificates}
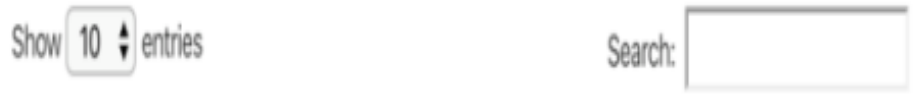

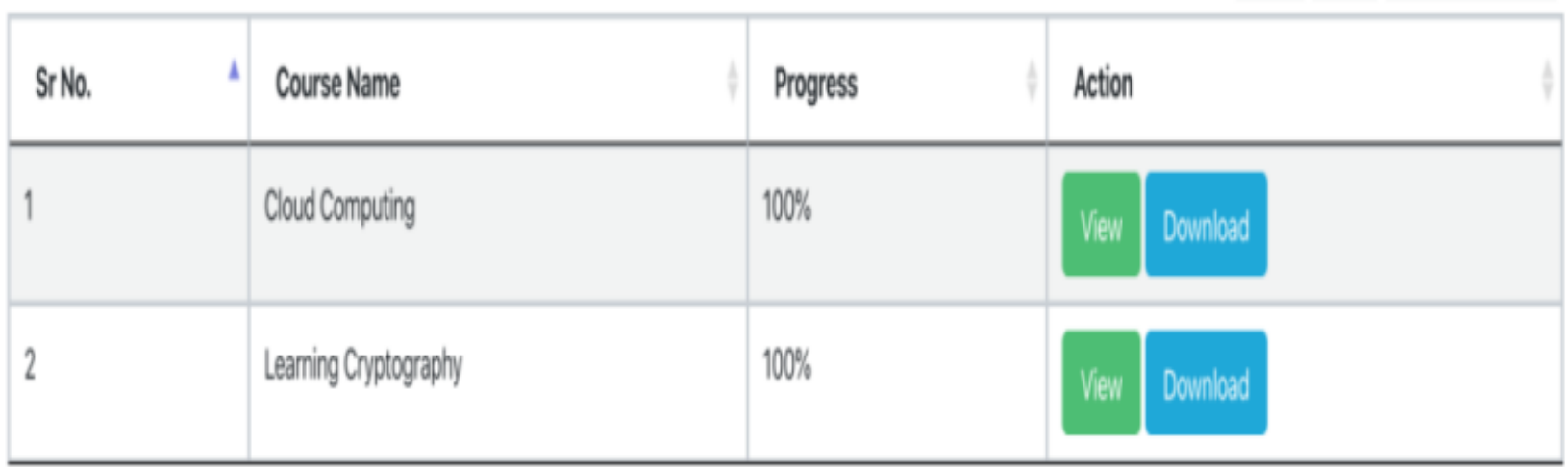

Showing 1 to 2 of 2 entries

\section{Figure 11: Generate Certificate Page}

(j) Course Page: The Coursepage, as shown in figure 12, allows the admin to view and manage courses currently registered on the elearning system. 


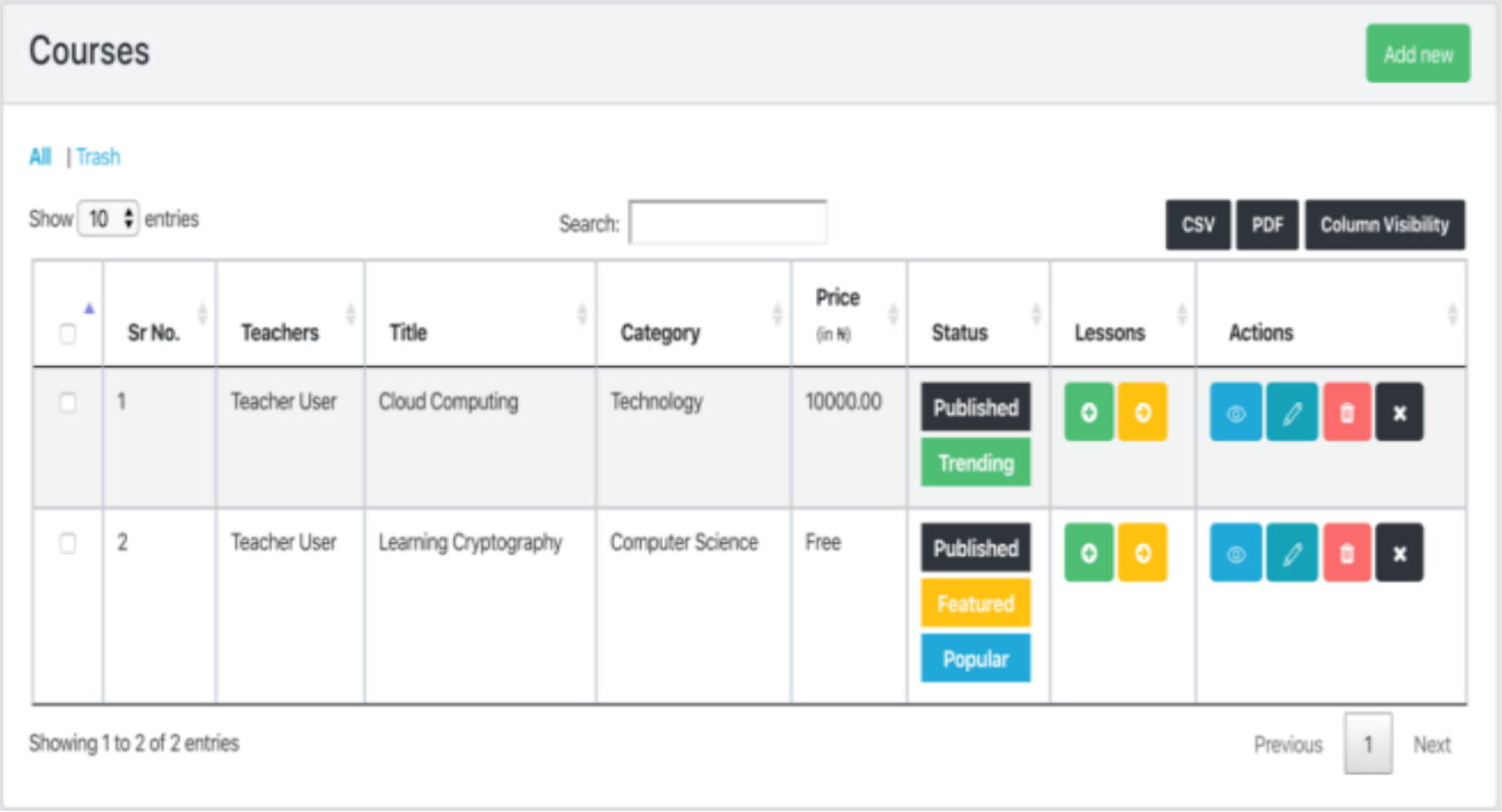

Figure 12: Course Page

(k) Implementation of the Message Page: The message page, as shown in figure 13, 14, 15 and 16, allows the student to view and send messages in the e-learning management system.

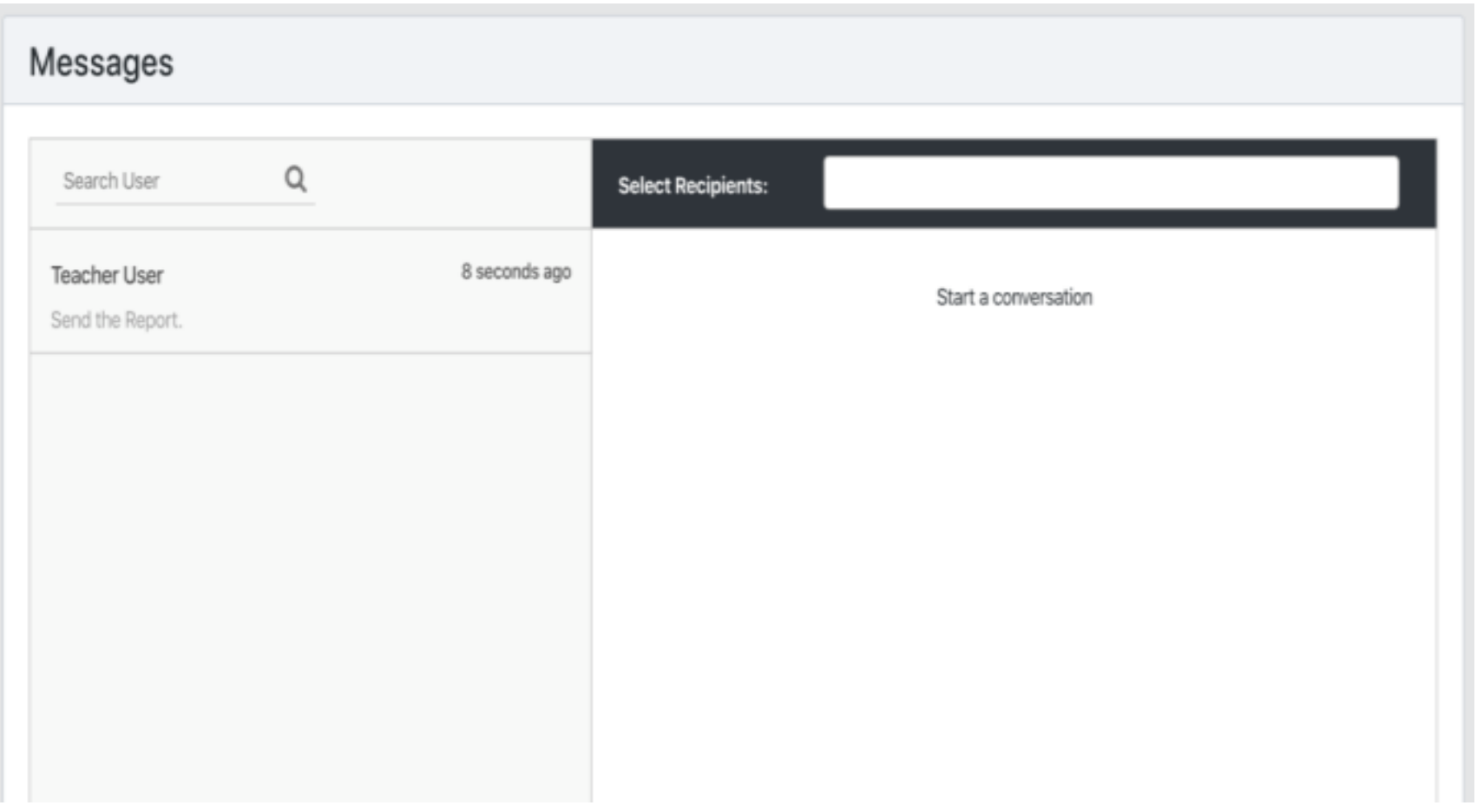

Figure 13: Message Page (1) 


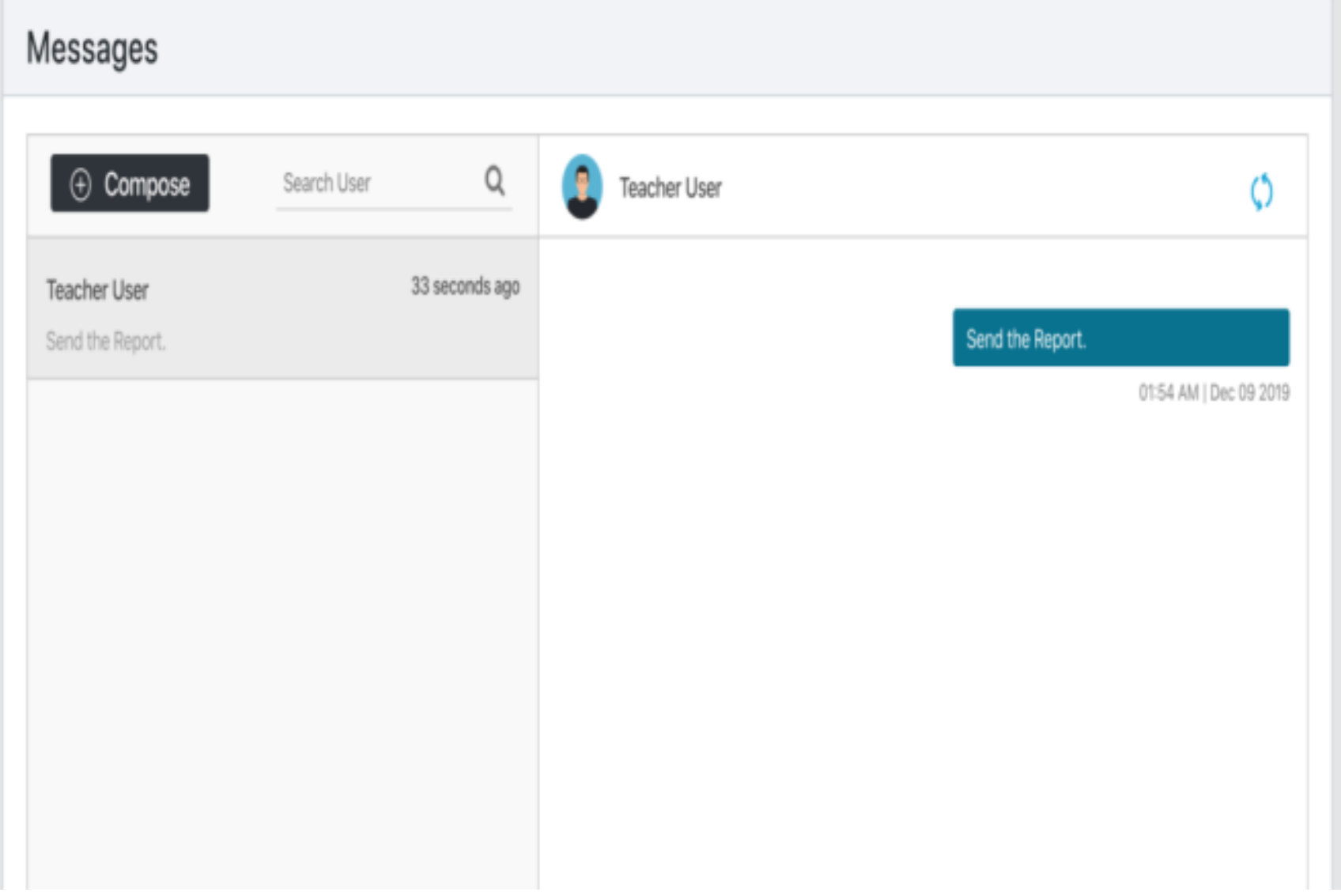

Figure 14: Message Page (2)

\section{Messages}

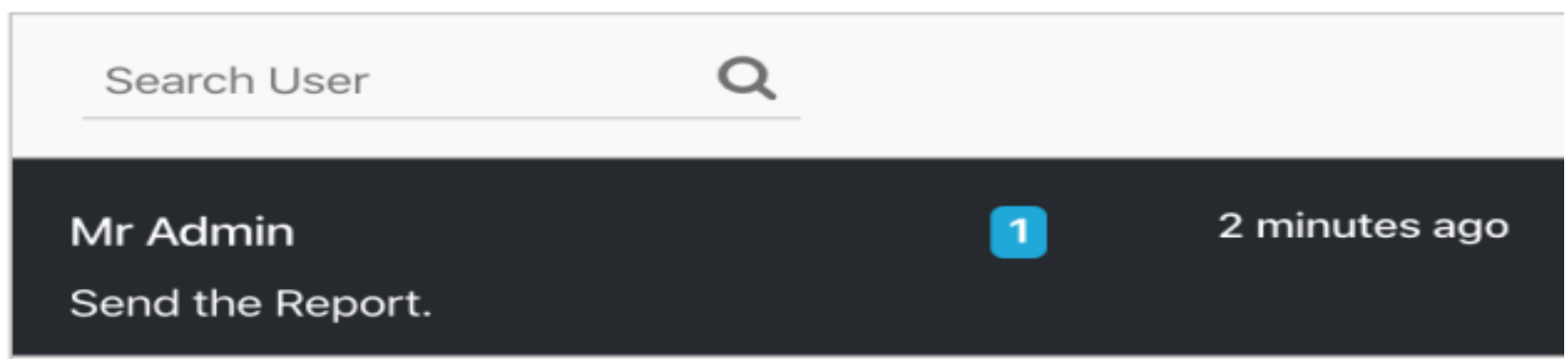

Figure 15: Message Page (3) 
Figure 16: Message Page (4)

(l)Course Category: The Course Categorypage, as shown in figure 17, allows the admin to add locations of courses in the e-learning management system.

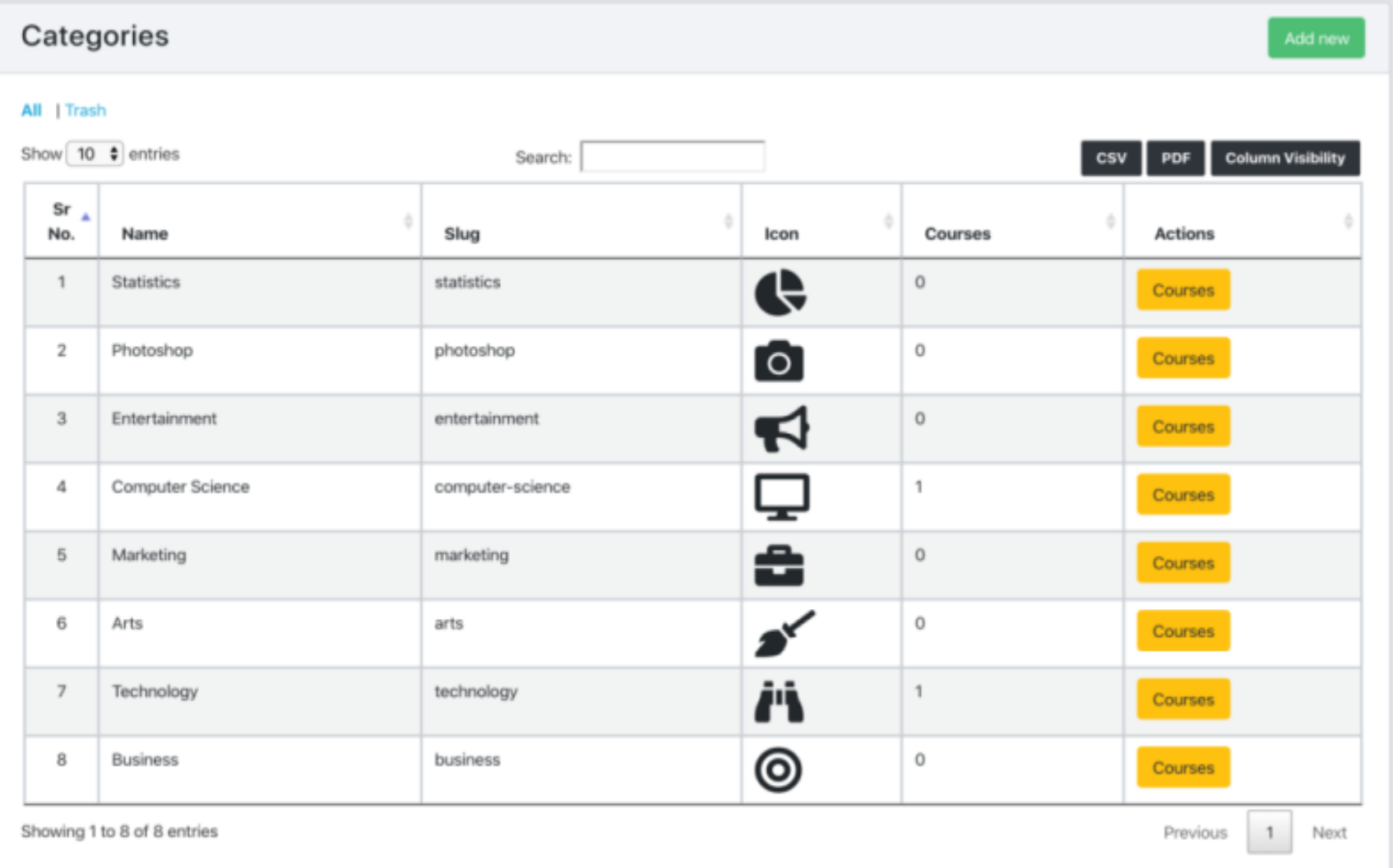

Figure 17: Course Category Page

(m) New Page/Create New Page: The New Page/Create New Page, as shown in figure 18, allows the admin to add and view pages in the e-learning management system. 


\section{Create Page}

Titie
Title
Slug

Input slug or it will be generated automatically

Content

B $\boldsymbol{I}$
Featured image ( $\max$ file size 10MB)

Choose file No file choser

\section{Figure 18: Create New Page}

(n) Menu Management Page: The Menu ManagementPage, as shown in figure 19, provides a means to manage the menu system that is displayed to both students and teachers when they logon to the e-learning management system.

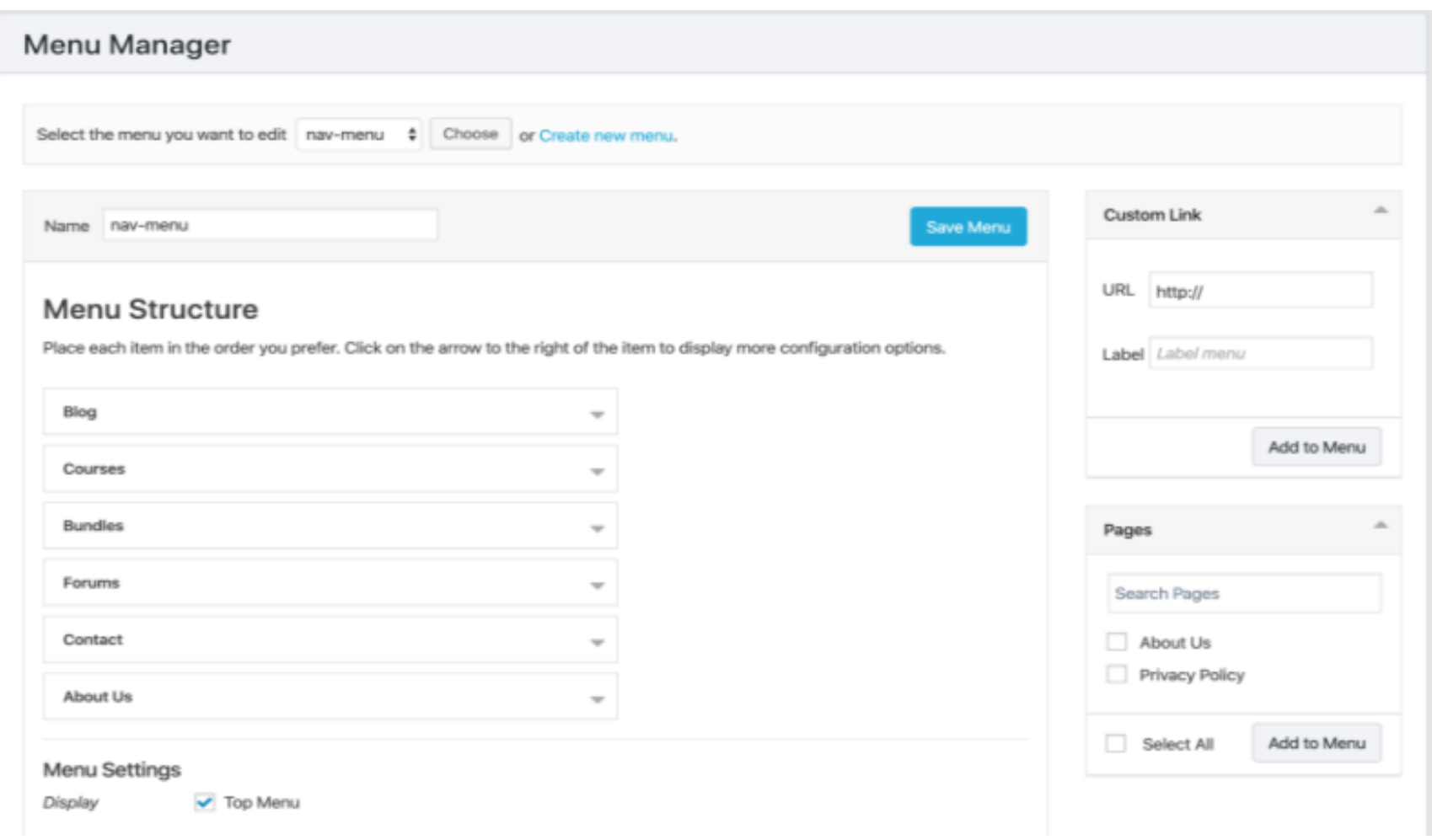

Figure 19: Menu Management Page

(o) User Dashboard: When the user inputs the correct login credentials, he is taken to the user dashboard, as shown in figure 20 . The dashboard is the command and control centre where the admin can add e-learning resources. 

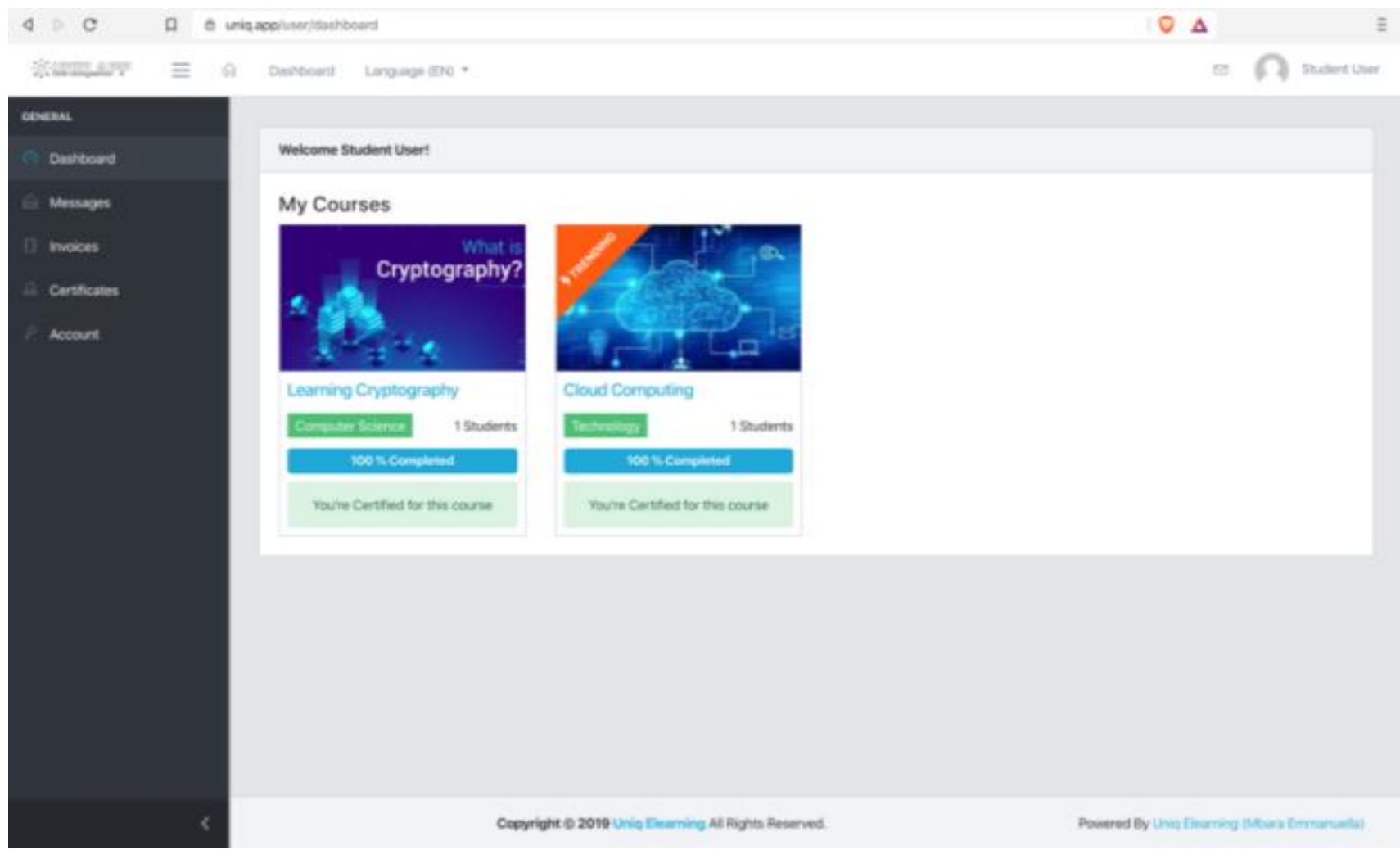

Figure 20: User Dashboard

\subsubsection{Output Design}

The E-learning system uses this module to convey information to the users. The output design screenshots include:

(a) Message pages: The messagepage, as shown in figure 21, 22, 23, and 24, allows the student to view and send messages in the elearning management system.
$\triangleleft \quad C$
๑) 3 uniq.app/user/messages
$\Delta$
三 त Dashboard Language (EN)
Q Student User

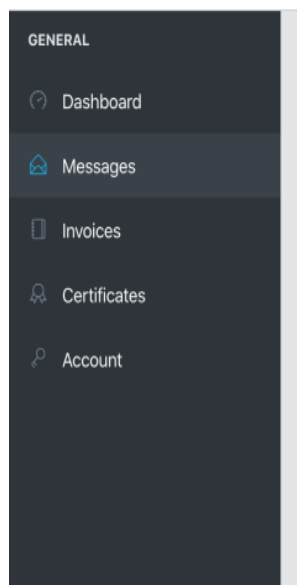

\section{Messages}

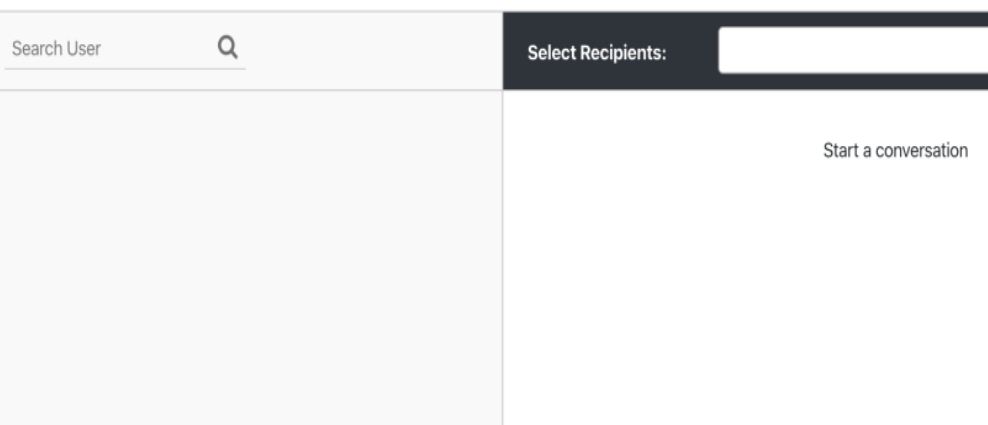

Figure 21: Message Page (1) 


\section{$\triangle \triangleright C \quad$ D $B$ uniq.app puser/messages:thread $=2$}

EA Dashooard Language (EN) *
$0 \Delta$

$\vdots$

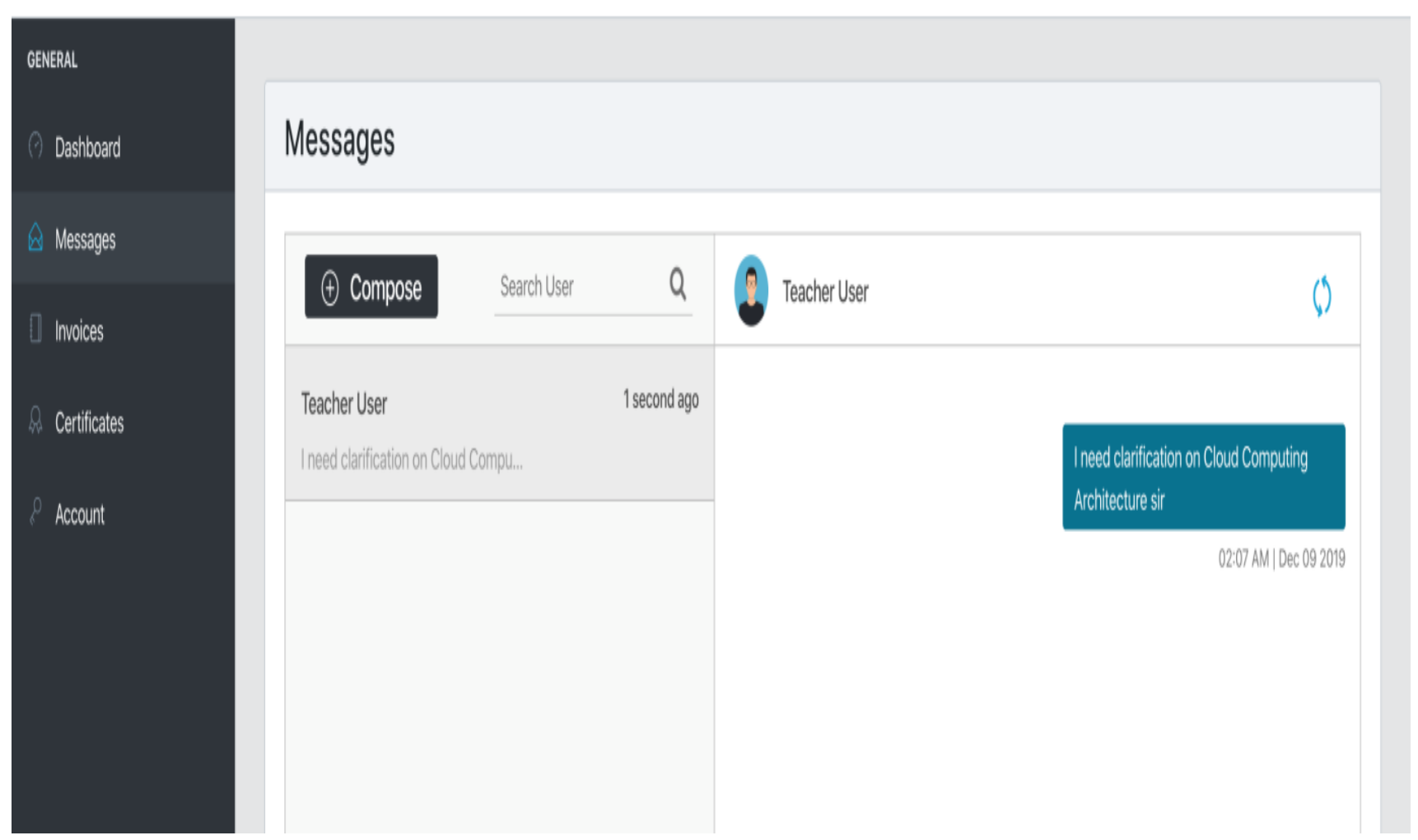

Figure 22: Message Page (2)

I need clarification on Cloud Computing

Architecture sir

02:07 AM | Dec 092019

Figure 23: Message Page (3) 


\section{Messages}

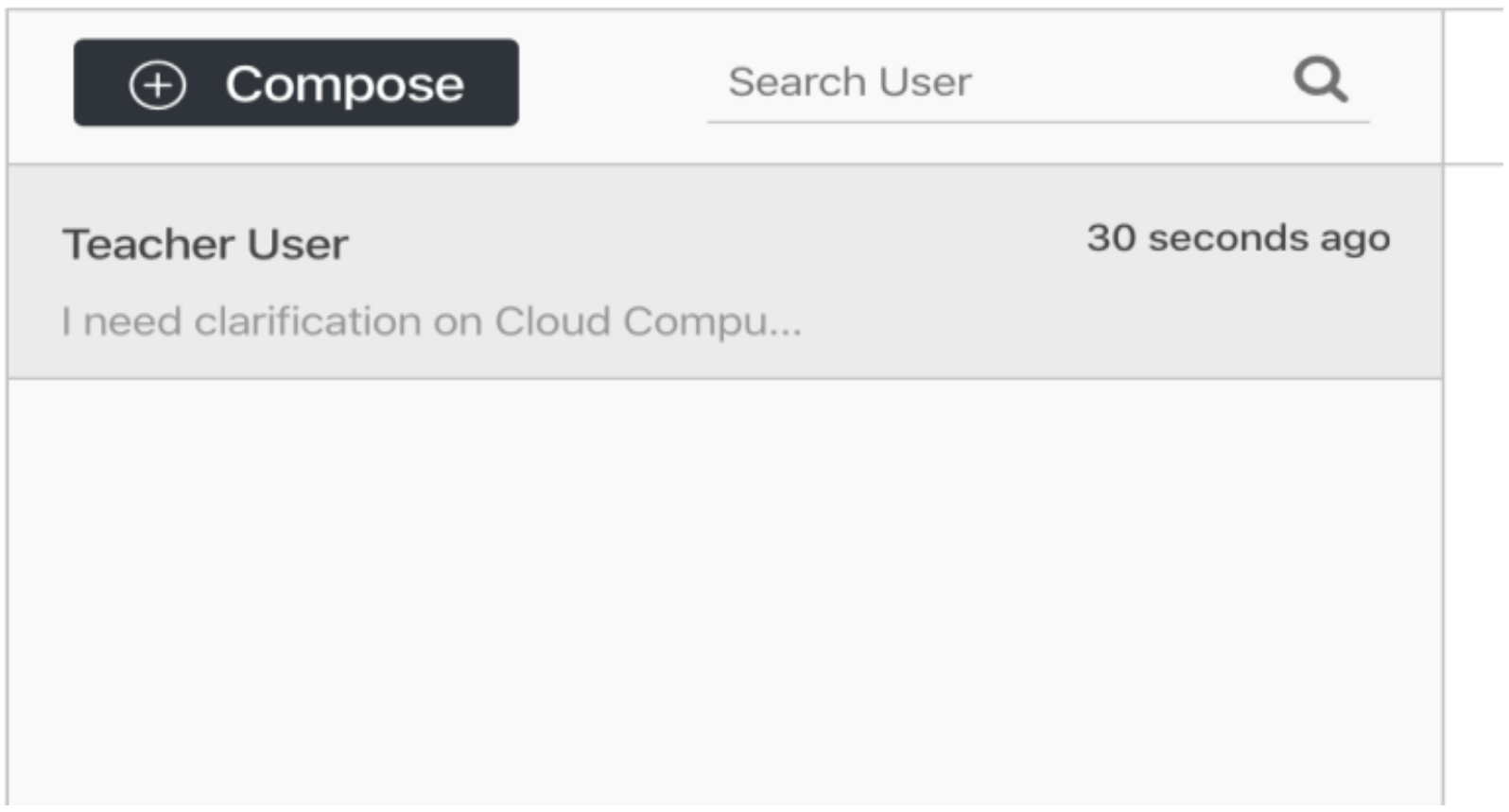

Figure 24: Message Page (4)

(b) User Profile Display Page: The user profile display page(figure 25) shows a user's profile information.

\section{My Account}

Profile Update Information Change Password

\begin{tabular}{|l||l|}
\hline Avatar & \\
\hline & Student User \\
\hline Name & student@uniq.app \\
\hline E-mail & Sun Dec 8 21:14:10 UTC 2019 (4 hours ago) \\
\hline Created At & Sun Dec 8 21:14:10 UTC 2019 (4 hours ago) \\
\hline Last Updated & \\
\hline
\end{tabular}

Figure 25:User Profile Display Page

(c) Student's Forum Page: This page (figure 26) allows the student to participate in the interactive forum of the e-learning platform. 


\section{$<$ How do Computers Work}

A computer works by combining input, storage, processing, and output. All the main parts of a computer system are involved in one of these four processes. Input: Your keyboard and mouse, for example, are just input units-ways of getting information into your computer that it can process.

The word computer refers to an object that can accept some input and produce some output. In fact, the human brain itself is a sophisticated computer, and scientists are learning more about how it works with each passing year. Our most common use of the word computer, though, is to describe an electronic device containing a microprocessor.

A microprocessor is a small electronic device that can carry out complex calculations in the blink of an eye. You can find microprocessors in many devices you use each day, such as cars, refrigerators and televisions. The most recognized device with a microprocessor is the personal computer, or PC. In fact, the concept of a computer has become nearly synonymous with the term PC.

When you hear PC, you probably envision an enclosed device with an attached video screen, keyboard and some type of a pointing device, like a

\section{Figure 26: Student's Forum Page}

(d) Invoice Page: The invoice page, as shown in figure 27, allows the student to view the invoices of the purchased courses.
\& C D 6 uniqappluseginvices
$0 \Delta$

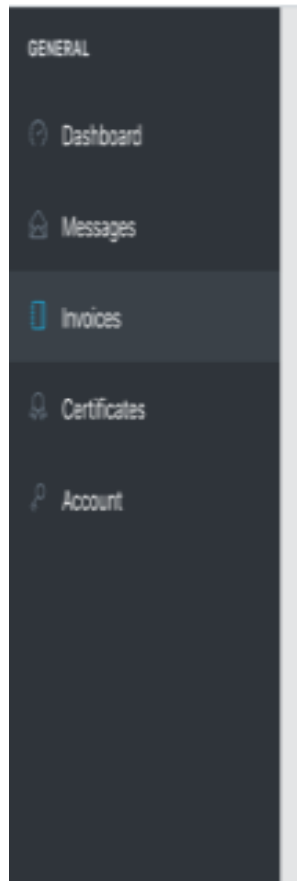

\section{Invoices}

\begin{tabular}{|c|c|c|c|c|}
\hline \multicolumn{2}{|c|}{ Show 10 ; entres } & scht: & & \\
\hline Srika. 4 & Order Date & 4) Anount & Action & \\
\hline 1 & C8 Dec, 2019 | 11151 PM & \#10000 & Ven & Dounloed \\
\hline
\end{tabular}

Showing 1 to 1 of 1 ertives

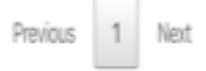

Figure 27: Student's Invoice Page

(e) Student's Generated Invoice Page: The generated invoicepage, as shown in figure 28 and 29, allows the student to view generated invoicein the e-learning management system. 


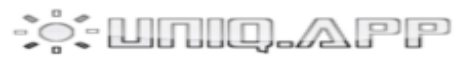

Business Details:

\section{Uniq Elearning}

Address: Port Harcourt, Rivers. Nigeria

Contact No.: +2348064719710

Email : info@uniq.app

Items:

\# ID

1 prod-2

Item Name
Cloud Computing

Total

Date: Sunday os December 2019

Invoice \#: 1

Customer Details:

Student User

Email : student@uniq.app

Figure 28: Student's Generated Invoice Page

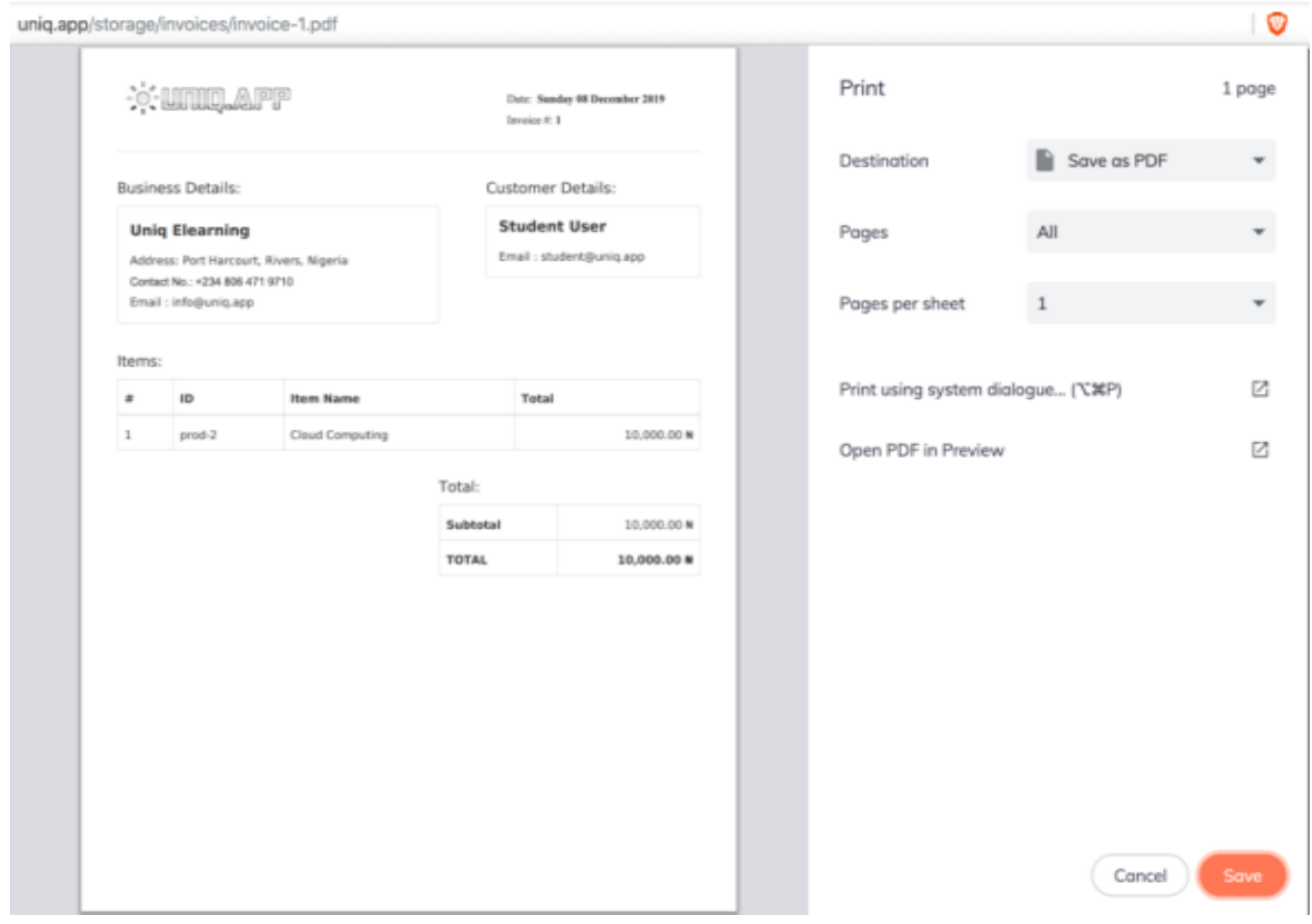

Figure 29: Student's Print Generated Invoice Page

(f) Student's Profile Page: The profile page, as shown in figure 30,allows the student to view profile details. 


\begin{tabular}{|l|l|}
\hline My Account \\
\hline Profile Update Information & Change Password \\
\hline Avatar & \\
\hline Name & Student User \\
\hline E-mail & student@uniq app \\
\hline Created At & Sun Dec 8 21:14:10 UTC 2019 (5 hours ago) \\
\hline Last Updated & Sun Dec 8 21:14:10 UTC 2019 (5 hours ago) \\
\hline
\end{tabular}

Figure 30: Student's Content Library Page

(g) Student's E-Learning Page: The e-learning page, as shown in figure 31, allows the student to view the courses that he/she was subscribed to.

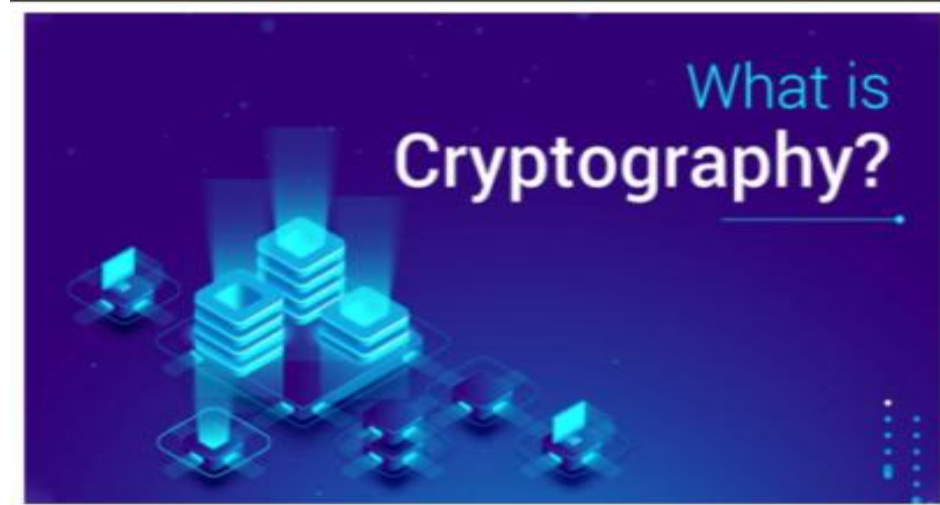

\section{Intro to Cryptography}

Cryptography or cryptology (from Ancient Greek: kpurtóc, romanized: kryptós "hidden, secret";

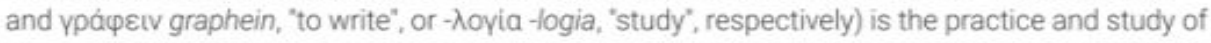
techniques for secure communication in the presence of third parties called adversaries. [2] More generally, cryptography is about constructing and analyzing protocols that prevent third parties or the public from reading private messages; various aspects in information security such as data confidentiality, data integrity, authentication, and non-repudiation are central to modern cryptography. Modern cryptography exists at the intersection of the disciplines of mathematics, computer science, electrical engineering, communication science, and physics. Applications of cryptography include electronic commerce, chip-based payment cards, digital currencies, computer passwords, and military communications.

\begin{tabular}{|c|c|c|}
\hline \multicolumn{3}{|c|}{ NEXT $*$} \\
\hline \multicolumn{3}{|c|}{ You're Certified for this course } \\
\hline \multicolumn{3}{|c|}{ Course Timeline: } \\
\hline INTRO TO & TOGRAPHY & 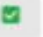 \\
\hline WHY WE $N$ & ENCRYPTION & $\Xi$ \\
\hline $\begin{array}{l}\text { CRYPTOG } \\
\text { - TEST }\end{array}$ & & 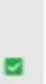 \\
\hline Chapters & & 3 \\
\hline Category & Computer & ence \\
\hline Author & Teac & User \\
\hline Progress & $100 \% \mathrm{Co}$ & \\
\hline
\end{tabular}

Figure 31:Student's E-learning Page

\subsection{Implementation and Testing}

The proposed system was implemented using HTML, CSS and J.S. as front end to display its content; PHP for the middle-end and MySQL Database Server was used as its back end and used for storing data saved by the user. The Elearning application software for this study passed through the unit and system test procedure, a standard testing procedure for software development. The test script can be executed via the command line using "vendor/bin/phpunitTestCaseName". Table 1 shows the test scripts for the various modules of the proposed system. 
Table 1: Test Script

\begin{tabular}{|c|c|c|c|}
\hline Functional Area & Test Name & Test Steps & Expected Results \\
\hline Homepage & Home page success & $\begin{array}{l}\text { Open your browser and } \\
\text { goto the app link (e.g } \\
\text { https://uniq.app) }\end{array}$ & $\begin{array}{l}\text { Show the landing page, courses, blog } \\
\text { posts, forums etc }\end{array}$ \\
\hline Login & Login Success & $\begin{array}{l}\text { 1. Enter valid username } \\
\text { \& password } \\
\text { 2. Click Login Now }\end{array}$ & $\begin{array}{l}\text { User login successful and access } \\
\text { dashboard }\end{array}$ \\
\hline Login & Login Failed & 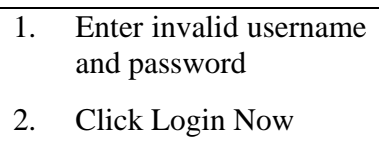 & $\begin{array}{l}\text { User login failed and redirect to login } \\
\text { page }\end{array}$ \\
\hline Sign-up & Create Account & $\begin{array}{ll}\text { 1. } & \text { Fill the form (all fields } \\
\text { required) } \\
\text { 2. } \\
\text { Click Register Now }\end{array}$ & $\begin{array}{l}\text { On successful registration, redirect to } \\
\text { the Login page and show the } \\
\text { registration success message }\end{array}$ \\
\hline Sign-up & Account Creation Failed & $\begin{array}{l}\text { 1. Partially fill the form } \\
\text { or enter the } \\
\text { mismatched password } \\
\text { or enter an email } \\
\text { already in use. } \\
\text { 2. Click Register Now }\end{array}$ & Show error messages. \\
\hline Course Creation & Course Creation Success & $\begin{array}{l}\text { 1. } \begin{array}{l}\text { Login with valid I.D. } \\
\text { (as admin or tutor) }\end{array} \\
\text { 2. } \begin{array}{l}\text { Goto Course } \\
\text { Management } \\
\text { Courses (fill all } \\
\text { required field) }\end{array} \\
\text { 3. Click Create }\end{array}$ & $\begin{array}{c}\text { Course Creation Successful, show } \\
\text { Course list }\end{array}$ \\
\hline Course Creation & Course Creation Failed & $\begin{array}{l}\text { 1. Login with valid I.D. } \\
\text { (as admin or tutor), } \\
\text { 2. } \begin{array}{l}\text { Goto Course } \\
\text { Management } \\
\text { Courses (leave } \\
\text { required fields empty) }\end{array} \\
\text { 3. } \\
\text { Click Create }\end{array}$ & Course Creation Failed, show errors \\
\hline $\begin{array}{l}\text { Course Category } \\
\text { Creation }\end{array}$ & $\begin{array}{c}\text { Course Category Creation } \\
\text { Success }\end{array}$ & $\begin{array}{ll}\text { 1. Login with valid I.D. } \\
\text { (as admin) } \\
\text { 2. } \begin{array}{l}\text { Goto Create Category } \\
\text { (fill all required field) }\end{array} \\
\text { 3. Click Create }\end{array}$ & $\begin{array}{c}\text { Course Category Creation Successful, } \\
\text { show Course Categorieslist }\end{array}$ \\
\hline $\begin{array}{l}\text { Course Category } \\
\text { Creation }\end{array}$ & $\begin{array}{c}\text { Course Category Creation } \\
\text { Failed }\end{array}$ & $\begin{array}{l}\text { 1. Login with valid I.D. } \\
\text { (as admin) } \\
\text { 2. } \begin{array}{l}\text { Goto Create Category } \\
\text { (leave required fields } \\
\text { empty) }\end{array} \\
\text { 3. Click Create }\end{array}$ & Course Creation Failed, show errors \\
\hline Lesson Creation & Lesson Creation Success & $\begin{array}{l}\text { 1. Login with valid I.D. } \\
\text { (as admin or tutor) } \\
\text { 2. } \begin{array}{l}\text { Goto Course } \\
\text { Management > Lesson } \\
\text { (fill all required field) }\end{array}\end{array}$ & $\begin{array}{c}\text { Lesson Creation Successful, show } \\
\text { Lessons list }\end{array}$ \\
\hline
\end{tabular}




\begin{tabular}{|c|c|c|c|}
\hline & & 3. Click Create & \\
\hline Lesson Creation & Lesson Creation Failed & $\begin{array}{l}\text { 1. Login with valid I.D. } \\
\text { (as admin or tutor) } \\
\text { 2. } \begin{array}{l}\text { Goto Course } \\
\text { Management }>\text { Lesson } \\
\text { (leave required fields } \\
\text { empty) }\end{array} \\
\text { 3. Click Create }\end{array}$ & Lesson Creation Failed, show errors \\
\hline Tests Creation & Tests of Creation Success & $\begin{array}{ll}\text { 1. } & \begin{array}{l}\text { Login with valid I.D. } \\
\text { (as admin or tutor) }\end{array} \\
\text { 2. } & \begin{array}{l}\text { Goto Course } \\
\text { Management >Tests } \\
\text { (fill all required fields) }\end{array} \\
\text { 3. Click Create }\end{array}$ & $\begin{array}{l}\text { Tests Creation Successful, show Tests } \\
\text { list }\end{array}$ \\
\hline Tests Creation & Test Creation Failed & $\begin{array}{l}\text { 1. } \begin{array}{l}\text { Login with valid I.D. } \\
\text { (as admin or tutor) }\end{array} \\
\text { 2. } \begin{array}{l}\text { Goto Course } \\
\text { Management > Tests } \\
\text { (leave required fields } \\
\text { empty) }\end{array} \\
\text { 3. Click Create }\end{array}$ & Test Creation Failed, show errors \\
\hline Questions Creation & Questions Creation Success & $\begin{array}{l}\text { 1. Login with valid I.D. } \\
\text { (as admin or tutor) } \\
\text { 2. } \begin{array}{l}\text { Goto Course } \\
\text { Management } \\
\text { Questions (fill all } \\
\text { required field) }\end{array} \\
\text { 3. Click Create }\end{array}$ & $\begin{array}{c}\text { Questions Creation Successful, show } \\
\text { Questions list }\end{array}$ \\
\hline Question Creation & Question Creation Failed & 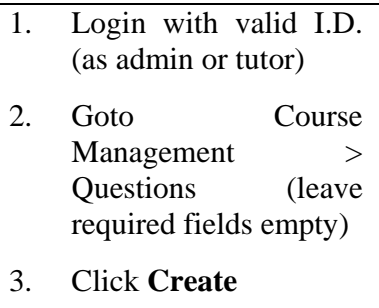 & Questions Creation Failed, show errors \\
\hline Tutors List & Tutors List & $\begin{array}{l}\text { 1. Login with valid I.D. } \\
\text { (as admin) } \\
\text { 2. Goto Teachers }\end{array}$ & View List of Created Tutors \\
\hline Orders List & Orders List & $\begin{array}{l}\text { 1. Login with valid I.D. } \\
\text { (as admin) } \\
\text { 2. Goto Orders }\end{array}$ & Show List of Course Orders \\
\hline Coupon Creation & Coupon Creation Success & $\begin{array}{l}\text { 1. Login with valid I.D. } \\
\text { (as admin) } \\
\text { 2. } \begin{array}{l}\text { Goto Coupon >Create } \\
\text { Coupon (fill all } \\
\text { required field) }\end{array} \\
\text { 3. Click Create }\end{array}$ & $\begin{array}{c}\text { Coupon Creation Successful, show } \\
\text { Coupon list }\end{array}$ \\
\hline Coupon Creation & Coupon Creation Failed & $\begin{array}{ll}\text { 1. } & \begin{array}{l}\text { Login with valid I.D. } \\
\text { (as admin) }\end{array} \\
\text { 2. } & \begin{array}{l}\text { Goto Coupon }>\text { Create } \\
\text { Coupon } \\
\text { required fields empty) }\end{array}\end{array}$ & Coupon Creation Failed, show errors \\
\hline
\end{tabular}




\begin{tabular}{|c|c|c|c|}
\hline & & 3. Click Create & \\
\hline Reports List & Reports & $\begin{array}{l}\text { 1. Login with valid I.D. } \\
\text { (as admin) } \\
\text { 2. Goto Reports }\end{array}$ & $\begin{array}{l}\text { Show List of Students and Sales } \\
\text { Records }\end{array}$ \\
\hline $\begin{array}{l}\text { Role and Permission } \\
\text { Management }\end{array}$ & Role and Permission Test & $\begin{array}{l}\text { 1. } \begin{array}{l}\text { Login with valid I.D. } \\
\text { (as admin) }\end{array} \\
\text { 2. } \begin{array}{l}\text { Goto Access > Role } \\
\text { Management }\end{array}\end{array}$ & $\begin{array}{l}\text { Show Roles and Permissions attached } \\
\text { to the roles }\end{array}$ \\
\hline $\begin{array}{l}\text { Roles and Permission } \\
\text { Management }\end{array}$ & Role Attachment & $\begin{array}{l}\text { 1. } \begin{array}{l}\text { Login with valid I.D. } \\
\text { (as admin) }\end{array} \\
\text { 2. } \begin{array}{l}\text { Goto Access > Role } \\
\text { Management }\end{array} \\
\text { 3. Edit or Add } \\
\text { 4. Create or Update }\end{array}$ & $\begin{array}{l}\text { Show Creation Form or the Edit form, } \\
\text { on success, redirect to Roles List Page }\end{array}$ \\
\hline Order Course & Course Ordering & $\begin{array}{l}\text { 1. Login with valid I.D. } \\
\text { (as a student) } \\
\text { 2. Select Course } \\
\text { 3. Click 'Buy Now' } \\
\text { 4. Make Payment } \\
\text { 5. Access Course }\end{array}$ & $\begin{array}{c}\text { Course Purchase Success, Access } \\
\text { Course }\end{array}$ \\
\hline Course Access & Course Access & $\begin{array}{l}\text { 1. Login with valid I.D. } \\
\text { (as a student) } \\
\text { 2. From the dashboard, } \\
\text { access the course you } \\
\text { wish } \\
\text { 3. Start Learning }\end{array}$ & $\begin{array}{l}\text { Show Course Details and All Learning } \\
\text { Materials Associated with the course. }\end{array}$ \\
\hline Take Test & Take Test & $\begin{array}{l}\text { 1. Login with valid I.D. } \\
\text { (as a student) } \\
\text { 2. SelectCourse } \\
\text { 3. Finish course outline } \\
\text { and Write test } \\
\text { 4. Click Submit }\end{array}$ & Show Course Assessment and report \\
\hline Forum Access & Forum Test & $\begin{array}{ll}\text { 1. } & \begin{array}{l}\text { Login with valid I.D. } \\
\text { (as a student) }\end{array} \\
\text { 2. } & \begin{array}{l}\text { Select Select a Fora } \\
\text { discussion }\end{array} \\
\text { 3. } & \begin{array}{l}\text { Participate } \\
\text { commenting by and } \\
\text { submitting comments }\end{array}\end{array}$ & $\begin{array}{l}\text { Show Forum room and all messages in } \\
\text { the forum }\end{array}$ \\
\hline Certificate & Certificate & $\begin{array}{ll}\text { 1. Login with valid I.D. } \\
\text { (as a student) } \\
\text { 2. Goto Certificates } \\
\text { 3. Select a Certificate to } \\
\text { View or Download }\end{array}$ & $\begin{array}{c}\text { Show Certificate List, View Certificate } \\
\text { Details and Print Certificate }\end{array}$ \\
\hline Message & Message & $\begin{array}{l}\text { 1. Login with valid I.D. } \\
\text { (as a student) } \\
\text { 2. Goto Messages } \\
\text { 3. Compose Message, } \\
\text { select recipient \& Send }\end{array}$ & $\begin{array}{l}\text { Show Message Inbox, create and view } \\
\text { a list of all in-out messages }\end{array}$ \\
\hline
\end{tabular}




\section{RESULTS AND DISCUSSION}

\subsection{Result Presentation}

The control matrix of the result from the evaluation of the existing system and the proposed method is shown in Table 2, Table 3 ,

Table 4 and Table 5, respectively.

Table 1:Control Matrix for Information Consumers (Existing system)

\begin{tabular}{|c|c|c|c|c|c|c|c|}
\hline $\begin{array}{c}\text { Performance } \\
\text { Indicator }\end{array}$ & $\begin{array}{c}\text { Extremely } \\
\text { Low }\end{array}$ & Low & Neutral & High & $\begin{array}{c}\text { Very } \\
\text { High }\end{array}$ & Rank & Judgment \\
\hline Likert scale Grade & $\mathbf{1}$ & $\mathbf{2}$ & $\mathbf{3}$ & $\mathbf{4}$ & $\mathbf{5}$ & & \\
\hline Security & 47 & 66 & 29 & 18 & 13 & $\mathbf{2}$ & weak \\
\hline System Upgrade & 35 & 61 & 32 & 26 & 19 & $\mathbf{2}$ & weak \\
\hline $\begin{array}{c}\text { Communicativeness of } \\
\text { Interface }\end{array}$ & 39 & 42 & 35 & 30 & 27 & $\mathbf{2}$ & weak \\
\hline
\end{tabular}

Table 3: Control Matrix for Independent Experts (Existing System)

\begin{tabular}{|c|c|c|c|c|c|c|c|}
\hline $\begin{array}{c}\text { Performance } \\
\text { Indicator }\end{array}$ & $\begin{array}{c}\text { Extremely } \\
\text { Low }\end{array}$ & Low & Neutral & High & $\begin{array}{c}\text { Very } \\
\text { High }\end{array}$ & Rank & Judgment \\
\hline Likert scale Grade & $\mathbf{1}$ & $\mathbf{2}$ & $\mathbf{3}$ & $\mathbf{4}$ & $\mathbf{5}$ & & \\
\hline Security & 47 & 66 & 29 & 18 & 13 & $\mathbf{2}$ & weak \\
\hline $\begin{array}{c}\text { System Upgrade } \\
\text { Communicativeness of } \\
\text { Interface }\end{array}$ & 35 & 61 & 32 & 26 & 19 & $\mathbf{2}$ & weak \\
\hline
\end{tabular}

The gap analysis shows that the existing system has limitations in the key performance indicators (security, system upgrade, and communicativeness of interface)

Table 4: Control Matrix for Independent Experts (Evaluation of the Unique System)

\begin{tabular}{|c|c|c|c|c|c|c|c|}
\hline Performance indicator & $\begin{array}{c}\text { Extremely } \\
\text { Low }\end{array}$ & Low & Neutral & High & $\begin{array}{c}\text { Very } \\
\text { High }\end{array}$ & Rank & Judgment \\
\hline Likert Scale Grade & $\mathbf{1}$ & $\mathbf{2}$ & $\mathbf{3}$ & $\mathbf{4}$ & $\mathbf{5}$ & & Strong \\
\hline Security & 0 & 0 & 2 & 3 & 20 & 5 & 5 \\
\hline System Upgrade & 0 & 0 & 0 & 7 & 18 & 5 & Strong \\
\hline $\begin{array}{c}\text { Communicativeness of } \\
\text { Interface }\end{array}$ & 0 & 0 & 2 & 2 & 23 & 5 \\
\hline
\end{tabular}

Table 5: Control Matrix for Information Consumers (Evaluation of the Proposed System)

\begin{tabular}{|c|c|c|c|c|c|c|c|}
\hline Likert Scale Grade & $\mathbf{1}$ & $\mathbf{2}$ & $\mathbf{3}$ & $\mathbf{4}$ & $\mathbf{5}$ & & \\
\hline Security & 0 & 0 & 2 & 2 & 21 & 5 & Strong \\
\hline System Upgrade & 0 & 0 & 4 & 6 & 15 & 5 & Strong \\
\hline $\begin{array}{c}\text { Communicativeness of } \\
\text { Interface }\end{array}$ & 0 & 0 & 0 & 1 & 24 & 5 & Strong \\
\hline
\end{tabular}


From the evaluation made by the Independent Experts(IEs) and Information Consumers(I.C.s), the unique system has succeeded in overcoming the bottlenecks posed by the existing system, namely its weak performance indicators.

\subsection{Discussion}

In this section, we answered the raised research questions.

1) To what extent do the weaknesses of the existing Elearning system for tertiary institution affect learning in tertiary institutions?

From the analysis carried out on the current E-learning system using Delphi method [13], it shows that the existing Elearning system has some weaknesses in terms of security, system upgrade, and communicativeness of interface. This has made online learning not conducive for the users of the existing E-learning system.

2) To what extent does the existing system as a whole differ from the enhanced E-learning application?

The proposed method has a wiki forum, upload video courses, create an assignment and live chat features. These features create a conducive learning environment for users of the proposed E-learning application software. However, these features are deficient in the existing E-learning system.

3) To what extent does the enhanced e-learning system improve over the current e-learning system?

The enhanced e-learning system has successfully addressed the limitations of the existing e-learning system. The results of the independent experts and information consumers from the analysis carried out shows that the enhanced e-learning system has improved security features, improved system upgradeability, and improved communicativeness of interface when compared to the existing e-learning system

\section{CONCLUSION}

The computerized automated enhanced e-learning system for tertiary institutions will provide better services for the students. Priority was on problem elimination of existing system and quality improvement of teaching in tertiary institutions. The software model used is the Structured System Analysis and Design Methodology. An improved security feature of the computerized system was also employed to avoid an unauthorized person or persons having access to data. The communicativeness of the interface of the proposed method was improved as well as the system upgrade feature.With the unique enhanced E-learning system, administrators would be able to control and streamline operations significantly. The enhanced system would also enable them to improve their response time to the demands of students because it automates the entire learning process.

\section{REFERENCES}

[1] E. Engelbrecht, "Adapting to changing expectations: postgraduate students' experience of an e-learning Tax Program". Computers and Education, 45, 2, 217-229, 2005.

[2] Federal Ministry of Education, "Ten-year Strategic Plan”, "Federal Ministry of Education “, Abuja, 2007.

[3] Federal Republic of Nigeria, "National Policy of Education $\left(4^{\text {th }}\right.$ ed)," "Nigeria Educational Research and Development Council", Abuja, 2004.

[4] O.Awodele, S. Idowu, V. J. Joshua, O.Anjorin, A.Adedire, and V. Akpore, "An Enhanced Learning Environment for Institutions: Implementing i-Converge's Pedagogical Model," "Issues in Informing Science and Information Technology”, 7(10), 41-59, 2010

[5] B. Gherardini, "E-learning methodologies: A guide for designing and developing e-learning courses," "Food and Agriculture Organisation of the United Nations, " Pp. 1$141,2011$.

[6] J. T. Torruam, “Application of E-Teaching and ELearning in Nigerian Educational System," "Academic Research International”, 3(1), 30-36, 2012.

[7] I. E.Onwuka, "Web-based Virtual Classroom System Model for Tertiary Institutions". "African Educational Research Network,"|20(19), 18-20, 2012.

[8] F. A. Adesuyi, A. N. Victor, O. Oluwafemi, and. C. Uchenna,"Cost-Effective Multimedia E-Learning Application for Nigerian Higher Institutions", "Computer Science and Information Technology,"2(2), 79-86, 2014.

[9] A. E. Khedr, and A. M. Idrees, "Enhanced e-Learning System for e-Courses Based on Cloud Computing," "Journal of Computers", 12(1), 10-19, 2015.

[10] M. Ajinaja,"The Design and Implementation of a Computer-Based Testing System Using ComponentBased Software Engineering", "International Journal of Computer Science and Technology”, 8(1), 58-65, 2017.

[11] S. S. Kyari,M. E. Adiuku-Brown, H.Abechi, H. Pyochi, and R. T. Adelakun, "E-Learning in Tertiary Education in Nigeria: Where Do We,"International Journal of Education and Evaluation", 4(9), 1-10, 2018.

[12] O.S. Salawudeen, "E-learning Technology","The Nigerian Experience, Roger Printing and Publishing limited", Abuja, Nigeria, 2010.

[13] R. Vaziri and M. Mohsenzadeh, "A Questionnaire Based Data Quality Methodology," "International Journal of Database Management Systems", Vol. 4, No. 2, 2012.

[14] W. Horton, "Leading e-Learning". American Society for Training and Development, 2001. 